\title{
HUBUNGAN STATUS GIZI DAN USIA GESTASI TERHADAP KEMAMPUAN MOTORIK HALUS, MOTORIK KASAR, BAHASA DAN PERSONAL SOSIAL ANAK UMUR 4-6 TAHUN DI TK NEGERI PEMBINA PANCUR BATU TAHUN 2017
}

\author{
Tiurlan Mariasima Doloksaribu, Johani Dewita Nasution \\ Jurusan Keperawatan Poltekkes Kemenkes Medan
}

\begin{abstract}
Abstrak
Status gizi adalah ekspresi dari keadaan keseimbangan dalam bentuk variabel tertentu atau perwujudan nutrisi dalam bentuk variabel tertentu. Empat kategori Status gizi anak yaitu gizi buruk, gizi sedang, gizi baik dan gizi lebih. Status gizi anak berpengaruh pada setiap tahapan perkembangan anak.Empat sektor kemampuan perkembangan anak yaitu motorik halus, motorik kasar, bahasa dan personal sosial. Kemampuan perkembangan anak dipengaruhi oleh faktor herediter dan faktor lingkungan termasuk diantaranya status gizi dan usia gestasi anak.

Tujuan dari penelitian ini adalah untuk mengetahui hubungan status gizi dan usia gestasi terhadap kemampuan motorik halus, motorik kasar, bahasa dan personal sosial anak usia 4 sampai 6 tahun di TK Negeri Pembina, Pancur Batu Kabupaten Deli Serdang.

Metode penelitian adalah analitik korelasi dengan rancangan cross sectional study. Alat yang digunakan dalam pengumpulan data adalah kuisioner, timbangan BB, alat ukur TB dan kuesioner Denver II.

Populasi dalam penelitian ini adalah anak usia 4-6 tahun yang merupakan murid-murid di TK Negeri Pembina, Pancur Batu Kabupaten Deli Serdang. Sampel diambil dengan tehnik total sampling sebanyak 83 orang anak. Analisis data menggunakan uji chi-square.

Hasil penelitian menunjukkan bahwa tidak dapat ditarik hubungan antar dua variabel dimana salah satu variabel adalah usia gestasi, disebabkan data pada usia gestasi tidak memiliki sebaran yang proporsional (usia gestasi normal 83 responden (98.8\%) sedangkan usia gestasi tidak normal 1 responden (1.2\%)). Hubungan status gizi terhadap kemampuan motorik halus dengan nilai $\mathrm{p}=1.000$, status gizi terhadap motorik kasar dengan nilai $\mathrm{p}=.231$, hubungan status gizi dengan kemampuan bahasa dengan nilai $\mathrm{p}=.727$ dan hubungan status gizi terhadap kemampuan personal sosial, nilai $\mathrm{p}=663$, dimana keseluruhan hasil dari uji statistik didapatkan bahwa nilai $\mathrm{p}>0.05$. Nilai $\mathrm{p}>0.05$ menunjukkan bahwa tidak ada hubungan antar variabel
\end{abstract}

Kata Kunci : status gizi, usia gestasi, motorik halus, motorik kasar, bicara dan bahasa, sosialisasi dan kemandirian.

\section{PENDAHULUAN}

Perbedaan status gizi balita berpengaruh pada setiap perkembangan anak, dimana konsumsi gizi yang tidak terpenuhi dengan baik akan menghambat perkembangan balita. Balita yang mengalami kekurangan gizi rentan mengalami infeksi, peradangan kulit dan keterbatasan perkembangan meliputi kognitif, motorik, bahasa dan keterampilan dibandingkan dengan balita yang memiliki status gizi baik (Anwar, 2004). Lindawati (2013), menyebutkan bahwa anak usia prasekolah dengan kriteria status gizi kurang, sebanyak 66,7\% mengalami kemampuan perkembangan tidak sesuai dengan umurnya, sedangkan anak dengan kriteria status gizi normal, mayoritas dapat mencapai kemampuan perkembangan sesuai umurnya $(67,2 \%)$.
Indonesia memasuki masalah gizi ganda, dimana masalah kurang gizi belum teratasi sementara di sisi lain sudah muncul masalah kelebihan gizi, yang kedua-duanya sangat berpengaruh pada kemampuan perkembangan anak. Anak balita termasuk didalamnya usia 3 -5 tahun, merupakan golden period atau periode emas dimana perkembangan otak mencapai 90\%, dan pada masa ini perlu diberikan nutrisi dan dilakukan stimulasi yang terbaik (Soetjiningsih, 2014).

Riset Kesehatan Dasar (RISKESDAS), 2013, diperoleh bahwa prevalensi gizi kurang pada Balita $(\mathrm{BB} / \mathrm{U} \leq \mathrm{SD})$ menunjukkan peningkatan dimana tahun 2010, sebanyak 19,3\% menjadi 19,6\% tahun 2013. Sejak tahun 2010 sampai 2013, terjadi pertambahan prevalensi balita pendek-kurus $(5,3 \%)$, balita pendeknormal $(2,1 \%)$ dan normal-gemuk $(0,3 \%)$. Santoso (2008) mendapatkan bahwa gizi kurang berdampak pada sumber daya manusia yang buruk untuk masa 
yang akan datang, dimana anak kurang mampu mengikuti pelajaran, tidak dapat membaca dengan lancar, berpenampilan kurang rapi, ceroboh, mudah lupa, gagal dalam memahami perintah, anak menjadi bodoh dan cenderung dihindari teman-temannya karena kurang dapat bekerja sama atau bermain bersama dalam permainan kelompok, sehingga anak tersisih dari pergaulan teman sebayanya. Status gizi yang buruk akan menghambat keterampilan motorik halus, motorik kasar, intelektual, emosional, sosial, moral dan kepribadian (Syamsu, 2012).

Surbaningsih, S., \& Rohmah, F., (2015), terdapat hubungan antara status gizi dengan perkembangan motorik halus balita usia 4-5 tahun di TK ABA Gendingan Yogyakarta. Penelitian Madiyantiningtias, E.H., (2015), terdapat hubungan status gizi anak usia 3-5 tahun dengan perkembangan motorik halus di Puskesmas Miri-Sragen. Begitu juga penelitian Anggraeni, M, N (2014) terdapat hubungan antara status gizi anak dengan perkembangan motorik halus pada anak usia 3-5 tahun di Kabupaten Purworejo, dengan $P$ value $0,000<$ a: 0,05 .

Salah satu program pokok Puskesmas yang harus dilakukan secara menyeluruh dan terkoordinasi, yang diselenggarakan dalam bentuk kemitraan antara keluarga, masyarakat dan tenaga professional adalah program SDIDTK (Stimulasi Deteksi dan Intervensi Dini Tumbuh Kembang) anak. Anak usia prasekolah (3-5 tahun) adalah kelompok usia yang memerlukan perhatian lebih terhadap kebutuhan gizinya, karena kekurangan pemenuhan kebutuhan gizinya pada masa anak-anak selain akan mengakibatkan gangguan pada pertumbuhan jasmaninya juga akan menyebabkan gangguan perkembangan mental anak. Anak yang menderita kurang gizi tidak dapat mencapai tinggi badan yang seharusnya dapat dicapai setelah mencapai usia dewasa (Soetjiningsih, 2007).

Berat badan berkaitan dengan gizi bayi dan merupakan gambaran jumlah protein, lemak, air dan mineral pada tulang (Supariasa, et al, 2002). Pertambahan berat badan lahir meningkat seiring pertambahan usia gestasi. Gestasi atau kehamilan adalah rangkaian peristiwa berkembangnya ovum menjadi fetus penuh setelah mengalami fertilisasi (Guyton, 2008). Secara umum pertambahan berat badan ibu hamil terjadi selama trimester I sebanyak 1 $\mathrm{kg}$, trimester ke II seberat $3 \mathrm{~kg}$ dan trimester ke II mencapai $6 \mathrm{~kg}$ dimana pertambahan berat badan ibu hamil pada trimester III didominasi oleh pertambahan berat janin yaitu penimbunan lemak tubuh dan perkembangan otak yang cepat (Soetjiningsih, 2012). Pada umumnya, bayi yang tidak cukup bulan (terutama pada kelahiran kurang dari 32 minggu) mempunyai resiko lebih tinggi untuk meninggal, sakit dan kegagalan pertumbuhan (WHO, 2003). Windari, F., dan Fitriyanti, E., (2014), menyatakan bahwa terdapat hubungan antara umur kehamilan dengan kejadian BBLR dimana nilai OR $=2,042$ yang berarti umur kehamilan <37 minggu beresiko 2,042 kali lipat untuk melahirkan BBLR dibandingkan pada ibu dengan umur kehamilan $\geq 37$ minggu. Hasil penelitian tersebut sesuai dengan teori yang dikemukakan oleh Winknjosastro (2007), bahwa bayi yang lahir pada umur kehamilan <36 minggu berisiko memiliki berat badan lahir rendah, sedangkan pada umur kehamilan $\geq$ 36 minggu tidak beresiko terjadi BBLR.

Hasil penelitian diatas melatarbelakangi peneliti untuk melakukan penelitian, bagaimana hubungan status nutrisi dan usia gestasi dengan kemampuan motorik halus, motorik kasar, bahasa dan personal sosial pada murid-murid di TK Negeri Pembina Pancur Batu Kabupaten Deli Serdang tahun 2017.

\section{METODE}

Penelitian dilaksanakan TK Negeri Pembina Pancur Batu Kabupaten Deli Serdang tahun 2017. Pengambilan sampel dengan tehnik total sampling sebanyak 83 responden.Penelitiananalitikkorelasi dengan desain crosssectional.Desain penelitian menggunakan cross sectional studyAnalisis data menggunakan uji korelasi Chi-Square dengan taraf kepercayaan 95\% untuk mengetahui hubungan status gizi dan usia gestasi dengan kemampuan motorik halus, motorik kasar, bahasa dan personal sosial, dengan hipotesis jika $p$ value $<\alpha(0,05)$

\section{HASIL}

\section{Analisa Univariat :}

Tabel 5.1 Distribusi Responden berdasarkan Umur (Tahun) di TK Negeri Pembina Pancur Batu Kabupaten Deli Serdang 2017

\begin{tabular}{lcc}
\hline Umur (Tahun) & $\mathrm{n}$ & $\%$ \\
\hline 4 sampai $<5$ & 3 & 3.6 \\
5 sampai $<6$ & 9 & 10.8 \\
6 & 71 & 85.5 \\
\hline Total & 83 & 100 \\
\hline
\end{tabular}

Dari tabel 5.1 diketahui bahwa mayoritas responden berusia 6 tahun sebanyak 71 responden $(85.5 \%)$ dan minoritas responden berusia 4 sampai $<5$ tahun sebanyak 3 responden $(3.6 \%)$

Tabel 5.2 Distribusi Responden berdasarkan Jenis Kelamin di TK Negeri Pembina Pancur Batu Kabupaten Deli Serdang 2017

\begin{tabular}{lll}
\hline Jenis Kelamin & $\mathrm{n}$ & $\%$ \\
\hline Laki-laki & 39 & 47.0 \\
Perempuan & 44 & 53.0 \\
\hline Total & 83 & 100 \\
\hline
\end{tabular}

Tabel 5.2 menunjukkan sebanyak 39 responden (47\%) berjenis kelamin laki-laki dan 44 responden (53\%) berjenis kelamin perempuan 
Tabel 5.3 Distribusi Frekwensi Responden berdasarkan Usia Gestasi, Status Gizi, Motorik Halus, Motorik Kasar, Bahasa dan

Personal Sosial di TK Negeri Pembina Pancur Batu Kabupaten Deli Serdang 2017

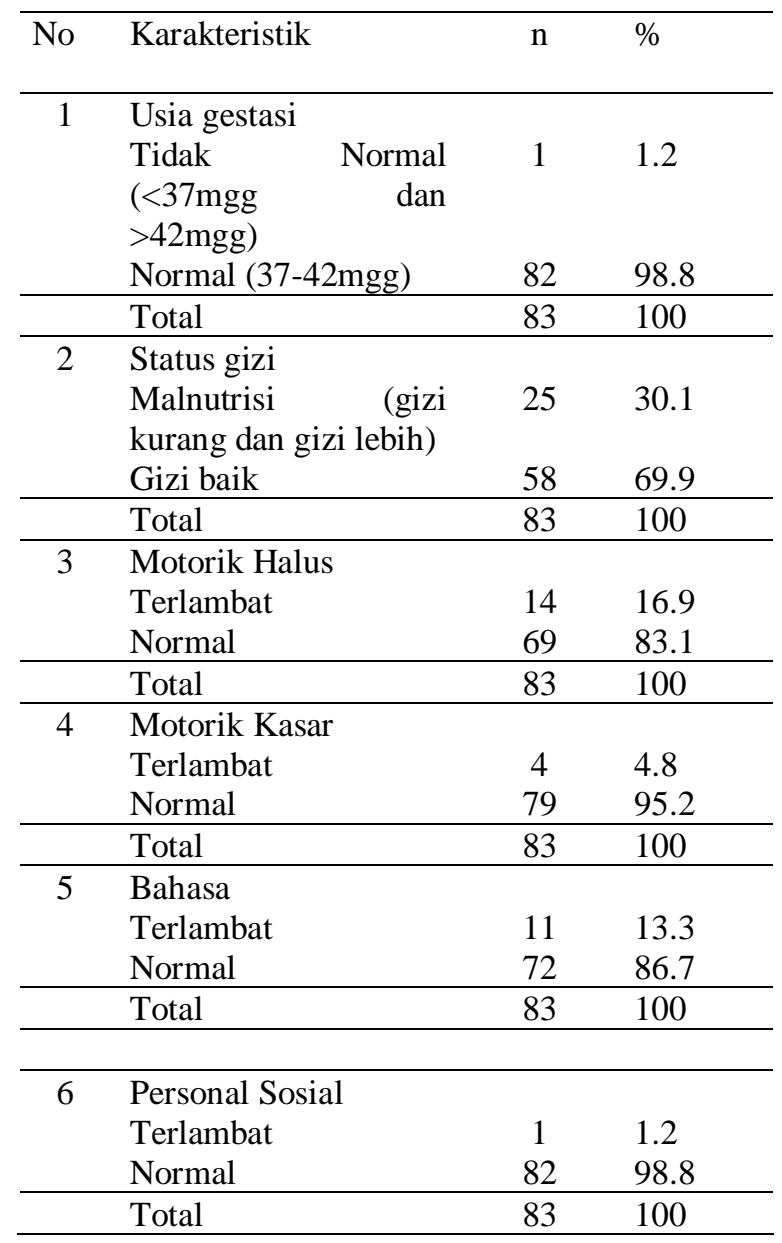

Dari tabel 5.3 diketahui terdapat 1 responden (1.2\%) dengan usia gestasi kurang dari 37 minggu, 25 responden (30.1\%) dengan status gizi malnutrisi (gizi kurang dan/atau gizi lebih), 14 responden (16.9\%) tidak mampu melakukan motorik halus sesuai dengan usianya, 4 responden (4.8\%) tidak mampu melakukan motorik kasar sesuai dengan usianya, 11 responden (13.3\%) tidak mampu berbahasa sesuai dengan usianya dan 1 responden (1.2\%) tidak mampu melakukan personal sosial sesuai dengan umurnya

Analisa Bivariat

Tabel 5.4 Hubungan Usia Gestasi terhadap Status Gizi Responden di TK Negeri Pembina Pancur Batu Kabupaten Deli Serdang 2017

\begin{tabular}{llllllll}
\hline \multirow{2}{*}{$\begin{array}{l}\text { Usia } \\
\text { Gestas }\end{array}$} & \multicolumn{2}{l}{ Status Gizi } & \multicolumn{1}{l}{ Malnutris } & \multicolumn{2}{l}{ Gizi } & Total & $\mathrm{P}_{\text {value }}$ \\
$\mathrm{i}$ & $\mathrm{i}$ & \multicolumn{2}{c}{ Baik } & & & \\
\cline { 2 - 8 } & $\mathrm{n}$ & $\%$ & $\mathrm{n}$ & $\%$ & $\mathrm{n}$ & $\%$ & \\
\hline Kuran & 0 & 0 & 1 & 100 & 1 & 10 & \multirow{2}{*}{$\begin{array}{l}1.00 \\
\mathrm{~g}\end{array}$} \\
Bulan & & & & & & 0 & 0 \\
\hline
\end{tabular}

\begin{tabular}{lllllll}
\hline Cukup & 25 & 30.5 & 5 & 69. & 8 & 10 \\
Bulan & & & 7 & 5 & 2 & 0 \\
\hline
\end{tabular}

Berdasarkan tabel 5.4 diketahui, dari 83 responden, terdapat 1 responden dengan usia gestasi kurang bulan namun memiliki status nutrisi gizi baik sedangkan 25 responden dengan usia gestasi cukup mengalami status gizi malnutrisi. Dari analisis bivariat didapati bahwa nilai $\mathrm{p}=1.000$, yang artinya tidak ada hubungan antara usia gestasi dengan status nutrisi

Tabel 5.5 Hubungan Status Gizi terhadap Kemampuan Motorik Halus Pada Anak Umur 4 Sampai 6 Tahun di TK Negeri Pembina Pancur Batu Kabupaten Deli Serdang Tahun 2017

\begin{tabular}{llllllll}
\hline \multirow{2}{*}{$\begin{array}{l}\text { Status } \\
\text { Gizi }\end{array}$} & \multicolumn{2}{l}{$\begin{array}{l}\text { Terlamb } \\
\text { at }\end{array}$} & \multicolumn{2}{c}{ Normal } & Total & $\mathrm{P}_{\text {value }}$ \\
\cline { 2 - 8 } & $\mathrm{n}$ & $\%$ & $\mathrm{n}$ & $\%$ & $\mathrm{n}$ & $\%$ & \\
\hline Malnutri & 4 & 16 & 2 & 84 & 2 & 10 & \\
si & & & 1 & & 5 & 0 & 1.00 \\
Gizi & 10 & 17. & 4 & 82. & 5 & 10 & 0 \\
Baik & & 2 & 8 & 8 & 8 & 0 & \\
\hline
\end{tabular}

Berdasarkan tabel 5.5, dari 25 responden dengan malnutrisi, sebanyak 4 responden (16\%) mengalami kemampuan motorik halus terlambat. Dari 58 responden dengan gizi baik, terdapat 10 responden $(17.2 \%)$ yang mengalami motorik halus terlambat. Dari analisis bivariat tabel diatas didapati bahwa nilai $\mathrm{p}=1.000$, yang artinya tidak ada hubungan antara status gizi dengan kemampuan motorik halus

Tabel 5.6 Hubungan Status Gizi terhadap Kemampuan Motorik Kasar Pada Anak Umur 4 Sampai 6 Tahun di TK Negeri Pembina Pancur Batu Kabupaten Deli Serdang Tahun 2017

\begin{tabular}{|c|c|c|c|c|c|c|c|}
\hline \multirow{3}{*}{$\begin{array}{l}\text { Status } \\
\text { Gizi }\end{array}$} & \multicolumn{6}{|c|}{ Motorik Kasar } & \multirow{3}{*}{$\begin{array}{l}\mathrm{P}_{\text {valu }} \\
\mathrm{e}\end{array}$} \\
\hline & \multicolumn{2}{|c|}{$\begin{array}{l}\text { Terlamb } \\
\text { at }\end{array}$} & \multicolumn{2}{|c|}{ Normal } & \multicolumn{2}{|c|}{ Total } & \\
\hline & $n$ & $\%$ & $\mathrm{n}$ & $\%$ & $\mathrm{n}$ & $\%$ & \\
\hline Malnutri & 0 & 0 & 2 & 100 & 2 & 10 & \\
\hline si & & & 5 & & 5 & 0 & 231 \\
\hline Gizi & 4 & 6.9 & 5 & 93. & 5 & 10 & .231 \\
\hline Baik & & & 4 & 1 & 8 & 0 & \\
\hline
\end{tabular}

Berdasarkan tabel 5.6, dari 25 responden dengan malnutrisi, seluruhnya memiliki kemampuan motorik kasar normal, sedangkan dari 58 responden dengan status gizi baik, 4 responden (6.9\%) mengalami keterlambatan kemampuan motorik kasar. Dari analisis bivariat tabel diatas didapati bahwa nilai $\mathrm{p}=0,231$ yang artinya tidak ada hubungan antara status gizi dengan kemampuan motorik kasar

Tabel 5.7 Hubungan Status Gizi terhadap Kemampuan Bahasa Pada Anak Umur 4 Sampai 6 Tahun di TK Negeri Pembina Pancur Batu Kabupaten Deli Serdang Tahun 2017 


\begin{tabular}{lccccccc}
\hline \multirow{2}{*}{$\begin{array}{l}\text { Status } \\
\text { Gizi }\end{array}$} & \multicolumn{9}{c}{$\begin{array}{c}\text { Terlamba } \\
\mathrm{t}\end{array}$} & \multicolumn{2}{c}{ Normal } & Total & $\begin{array}{c}\mathrm{P}_{\text {valu }} \\
\mathrm{nyyyyyyy}\end{array}$ & $\mathrm{n}$ & $\%$ & $\mathrm{n}$ & $\%$ & $\mathrm{n}$ & $\%$ & \\
\hline Malnutri & 4 & 16 & 2 & 84 & 2 & 10 & \\
si & & & 1 & & 5 & 0 & .727 \\
Gizi & 7 & 12.1 & 5 & 87. & 5 & 10 & \\
Baik & & & 1 & 9 & 8 & 0 & \\
\hline
\end{tabular}

Berdasarkan tabel 5.7, dari 25 responden dengan malnutrisi, 21 responden (84\%) memiliki kemampuan bahasa yang normal sedangkan dari 58 responden dengan status gizi baik, 7 responden (12.19\%) mengalami keterlambatan kemampuan bahasa. Dari analisis bivariat tabel diatas didapati bahwa nilai $\mathrm{p}=0,727$ yang artinya tidak ada hubungan antara status gizi dengan kemampuan bahasa

Tabel 5.8 Hubungan Status Gizi terhadap Kemampuan Personal Sosial Pada Anak Umur 4 Sampai 6 Tahun di TK Negeri Pembina Pancur Batu Kabupaten Deli Serdang Tahun 2017

\begin{tabular}{|c|c|c|c|c|c|c|c|}
\hline \multirow{3}{*}{$\begin{array}{l}\text { Status } \\
\text { Gizi }\end{array}$} & \multicolumn{4}{|c|}{ Personal Sosial } & \multirow{2}{*}{\multicolumn{2}{|c|}{ Total }} & \multirow{3}{*}{$\begin{array}{c}P_{\text {valu }} \\
\mathrm{e}\end{array}$} \\
\hline & \multicolumn{2}{|c|}{$\underset{t}{\text { Terlamba }}$} & \multicolumn{2}{|c|}{ Normal } & & & \\
\hline & $\mathrm{n}$ & $\%$ & $\mathrm{n}$ & $\%$ & $\mathrm{n}$ & $\%$ & \\
\hline Malnutri & 1 & 4.0 & 2 & 96 & 2 & 10 & \\
\hline si & & & 4 & & 5 & 0 & \\
\hline Gizi Baik & 0 & 0 & 5 & 10 & 5 & 10 & .663 \\
\hline & & & 8 & 0 & 8 & 0 & \\
\hline
\end{tabular}

Berdasarkan tabel 5.8, dari 25 responden dengan malnutrisi, 24 responden (96\%) memiliki kemampuan personal sosial yang normal dan 58 responden dengan status gizi baik seluruhnya memiliki kemampuan personal sosial normal. Dari analisis bivariat tabel diatas didapati bahwa nilai $\mathrm{p}=0,663$ yang artinya tidak ada hubungan antara status gizi dengan kemampuan personal sosial

Tabel 5.9 Hubungan Usia Gestasi terhadap Kemampuan Motorik Halus Pada Anak Umur 4 Sampai 6 Tahun di TK Negeri Pembina Pancur Batu Kabupaten Deli Serdang Tahun 2017

\begin{tabular}{lccccccc}
\hline \multirow{8}{*}{$\begin{array}{l}\text { Usia } \\
\text { Gestasi }\end{array}$} & \multicolumn{9}{c}{ Terlambat } & Normal & Total & $\mathrm{P}_{\text {value }}$ \\
\cline { 2 - 8 } & $\mathrm{n}$ & $\%$ & $\mathrm{n}$ & $\%$ & $\mathrm{n}$ & $\%$ & \\
\hline $\begin{array}{l}\text { Kurang } \\
\text { Bulan }\end{array}$ & 0 & 0 & 1 & 100 & 1 & 100 & \\
$\begin{array}{l}\text { Cukup } \\
\text { Bulan }\end{array}$ & 14 & 17.1 & 68 & 82.9 & 82 & 100 & 1.000 \\
\hline
\end{tabular}

Berdasarkan tabel 5.9 diketahui, dari 83 responden, terdapat 1 responden dengan usia gestasi kurang bulan namun memiliki kemampuan motorik halus normal sementara 14 responden dengan usia gestasi cukup mengalami dengan kemampuan motorik halus terlambat. Dari analisis bivariat didapati bahwa nilai $\mathrm{p}=1.000$, yang artinya tidak ada hubungan antara usia gestasi dengan kemampuan motorik halus

Tabel 5.10 Hubungan Usia Gestasi terhadap Kemampuan Motorik Kasar Pada Anak Umur 4 Sampai 6 Tahun di TK Negeri Pembina Pancur Batu Kabupaten Deli Serdang Tahun 2017

\begin{tabular}{lccccccc}
\hline \multirow{2}{*}{$\begin{array}{l}\text { Usia } \\
\text { Gestas }\end{array}$} & \multicolumn{9}{c}{$\begin{array}{c}\text { Terlamba } \\
\mathrm{i}\end{array}$} & \multicolumn{2}{c}{ t Normal } & Total & $\mathrm{P}_{\text {value }}$ \\
\cline { 2 - 8 } & $\mathrm{n}$ & $\%$ & $\mathrm{n}$ & $\%$ & $\mathrm{n}$ & $\%$ & \\
\hline Kuran & 0 & 0 & 1 & 100 & 1 & 10 & \\
$\mathrm{~g}$ & & & & & & 0 & 1.00 \\
Bulan & & & & & & & 0 \\
Cukup & 4 & 4.9 & 7 & 95. & 8 & 10 & \\
Bulan & & & 8 & 1 & 2 & 0 & \\
\hline
\end{tabular}

Berdasarkan tabel 5.10 diketahui, dari 83 responden, terdapat 1 responden dengan usia gestasi kurang bulan namun memiliki kemampuan motorik kasar normal sementara 4 responden $(4.9 \%)$ dengan usia gestasi cukup bulan memiliki kemampuan motorik kasar terlambat. Dari analisis bivariat didapati bahwa nilai $\mathrm{p}=1.000$, yang artinya tidak ada hubungan antara usia gestasi dengan kemampuan motorik kasar.

Tabel 5.11 Hubungan Usia Gestasi terhadap Kemampuan Bahasa Pada Anak Umur 4 Sampai 6 Tahun di TK Negeri Pembina Pancur Batu Kabupaten Deli Serdang Tahun 2017

\begin{tabular}{|c|c|c|c|c|c|c|c|}
\hline \multirow{3}{*}{$\begin{array}{l}\text { Usia } \\
\text { Gestasi }\end{array}$} & \multicolumn{4}{|c|}{ Bahasa } & \multirow{2}{*}{\multicolumn{2}{|c|}{ Total }} & \multirow{3}{*}{$\begin{array}{c}P_{\text {valu }} \\
\mathrm{e}\end{array}$} \\
\hline & \multicolumn{2}{|c|}{$\underset{t}{\text { Terlamba }}$} & \multicolumn{2}{|c|}{ Normal } & & & \\
\hline & $\mathrm{n}$ & $\%$ & $\mathrm{n}$ & $\%$ & $\mathrm{n}$ & $\%$ & \\
\hline Kuran & 0 & 0 & 1 & 100 & 1 & 10 & \\
\hline g & & & & & & 0 & \\
\hline Bulan & & & & & & & 1.000 \\
\hline Cukup & 11 & 13.4 & 7 & 86. & 8 & 10 & \\
\hline Bulan & & & 1 & 6 & 2 & 0 & \\
\hline
\end{tabular}

Berdasarkan tabel 5.11 diketahui, dari 83 responden, terdapat 1 responden dengan usia gestasi kurang bulan namun memiliki kemampuan bahasa normal sedangkan dari 82 responden dengan usia gestasi cukup bulan, 11 responden (13.4\%) memiliki kemampuan bahasa terlambat. Dari analisis bivariat didapati bahwa nilai $\mathrm{p}=1.000$, yang artinya tidak ada hubungan antara usia gestasi dengan kemampuan bahasa

Tabel 5.11 Hubungan Usia Gestasi berdasarkan Kemampuan Personal Sosial Pada Anak Umur 4 Sampai 6 Tahun di TK Negeri Pembina Pancur Batu Kabupaten Deli Serdang Tahun 2017

\begin{tabular}{|c|c|c|c|c|}
\hline \multirow{3}{*}{$\begin{array}{l}\text { Usia } \\
\text { Gestas } \\
\text { i }\end{array}$} & \multicolumn{2}{|c|}{ Personal Sosial } & \multirow[b]{2}{*}{ Total } & \multirow[b]{2}{*}{$\mathrm{P}_{\text {value }}$} \\
\hline & Terlamba & Normal & & \\
\hline & $\%$ & $\%$ & $\%$ & \\
\hline
\end{tabular}




\begin{tabular}{lccccccc} 
& & & & & & & \\
Kuran & 0 & 0 & 1 & 100 & 1 & 10 & \\
g & & & & & & 0 & 1.00 \\
Bulan & & & & & & & 0 \\
Cukup & 1 & 1.2 & 8 & 98. & 8 & 10 & \\
Bulan & & & 1 & 8 & 2 & 0 & \\
\hline
\end{tabular}

Berdasarkan tabel 5.11 diketahui, dari 83 responden, terdapat 1 responden dengan usia gestasi kurang bulan namun memiliki kemampuan personal sosial normal. Dari 82 responden dengan usia gestasi cukup bulan, mayoritas responden $(98.8 \%)$ memiliki kemampuan personal sosial normal. Dari analisis bivariat didapati bahwa nilai $\mathrm{p}=1.000$, yang artinya tidak ada hubungan antara usia gestasi dengan kemampuan personal sosial

\section{PEMBAHASAN}

\section{Hubungan usia gestasi dengan status nutrisi}

Usia gestasi adalah lama bayi berada dalam kandungan ibu dihitung sejak konsepsi sampai kelahiran anak yang dihitung dalam minggu. Status gizi merupakan ukuran keberhasilan pemenuhan kebutuhan nutrisi pada anak yang diindikasikan oleh berat badan dan tinggi badan berdasarkan jenis kelamin. Penelitian menunjukkan bahwa tidak ada hubungan antara usia gestasi dengan status nutrisi yang ditunjukkan oleh nilai $\mathrm{p}=1.000$ dimana $\mathrm{p}<0.05$. Pada anak yang memiliki riwayat usia gestasi kurang bulan memiliki kemampuan untuk mengalami maturitas ekstrauterine. Perawatan dan pemberian makanan dengan gizi yang baik akan meningkatkan pertumbuhan sehingga anak memiliki tinggi badan dan berat badan yang seimbang. Berat badan dan tinggi badan yang seimbang dikelompokkan dalam status gizi baik sehingga dapat bayi dengan riwayat usia gestasi kurang bulan memiliki status nutrisi yang baik

e) Hubungan usia gestasi dengan motorik halus, motorik kasar, bahasa dan personal sosial

Kemampuan perkembangan anak dipengaruhi oleh banyak faktor yaitu faktor herediter dan faktor lingkungan. Faktor herediter terdiri atas jenis kelamin dan umur anak. faktor lingkungan terdiri atas pengetahuan orang tua, pendapatan keluarga, tingkat pendidikan orangtua, stimulus yang diterima oleh anak, jumlah anak dalam keluarga, status gizi dan usia gestasi. Hasil pengelolaan data SPSS didapatkan bahwa hubungan usia gestasi dengan motorik halus memiliki nilai $\mathrm{p}=1.000$, hubungan usia gestasi dengan motorik kasar memiliki nilai $\mathrm{p}=0.231$, hubungan usia gestasi dengan perkembangan kemampuan bahasa memiliki nilai $\mathrm{p}=0.727$ dan hubungan usia gestasi dengan kemampuan perkembangan personal sosial memiliki nilai $\mathrm{p}=0.663$. Dapat disimpulkan bahwa pada penelitian ini, tidak terdapat hubungan antara usia gestasi dengan motorik halus, motorik kasar, bahasa dan personal sosial.

f) Hubungan status nutrisi dengan motorik halus, motorik kasar, bahasa dan personal sosial
Status nutrisi diartikan sebagai status kesehatan individu yang dihasilkan oleh keseimbangan antara kebutuhan dan pemenuhan kebutuhan nutrien. Pengukuran status gizi merupakan pengukuran yang didasarkan pada data antropometri serta biokimia dan riwayat diet,. Dalam penelitian ini indicator pengukuran nutrisi berdasarkan atas berat badan dan tinggi badan berdasarkan jenis kelamin.

Data hasil penelitian ini menunjukkan bahwa hubungan antara status nutrisi dengan kemampuan perkembangan motorik halus memiliki nilai $\mathrm{p}=1.000$, demikian juga hubungan status nutrisi dengan kemampuan perkembangan motorik kasar, bahasa dan personal sosial masing-masing dengan nilai $\mathrm{p}=1.000$.

Hasil penelitian menunjukkan bahwa tidak ada hubungan antara status nutrisi dengan kemapuan motorik halus, kemampuan motorik kasar, perkembangan kemampuan bahasa dan kemampuan personal sosial yang ditunjukkan oleh nilai $\mathrm{p}=1.000$ dimana nilai $\mathrm{p}<0.05$.

\section{KESIMPULAN}

1. Mayoritas responden umur 6 tahun sebesar 71 responden $(85.5 \%)$, laki-laki 39 responden $(47 \%)$ dan perempuan 44 responden $(53 \%)$.

2. 1 responden $(1.2 \%)$ usia gestasi kurang bulan dan 82 responden $(98.8 \%)$ usia gestasi cukup bulan

3. Terdapat 25 responden $(30.1 \%)$ status gizi malnutrisi (gabungan dari gizi buruk, gizi kurang dan gizi lebih) sedangkan 58 responden (69.9\%) dengan gizi baik

4. Sebanyak 14 responden (16.9\%) motorik halus terlambat dengan kata lain tidak mampu melakukan seluruh tes motorik halus sesuaiumurnya.

5. Sebanyak 4 responden (4.8\%) motorik kasar terlambat dengan kata lain tidak mampu melakukan seluruh tes motorik kasar sesuai umurnya.

6. Sebanyak 11 responden (13.3\%) kemampuan bahasanya terlambatartinya tidak mampu melakukan seluruh tes bahasa sesuai umurnya.

7. Terdapat 1 responden $(1.2 \%)$ perkembangan personal social terlambat dengan kata lain tidak mampu melakukan seluruh tes personal sosial sesuai umurnya.

8. Hasil penelitian menunjukkantidak ada hubungan antara status nutrisi dengan usia gestasi (nilai $\mathrm{p}>0.05$ )

9. Hasil penelitian menunjukkan bahwa tidak ada hubungan antara status nutrisi dengan kemampuan motorik halus, motorik kasar, bahasa dan personal sosial dimana nilai $\mathrm{p}>0.05$

10. Hasil penelitian menunjukkan bahwa tidak ada hubungan antara usia gestasi dengan kemampuan motorik halus, motorik kasar, bahasa dan personal sosial dimana nilai $\mathrm{p}>0.05$

\section{SARAN}

1. Kepala Sekolah dan Guru di TK Negeri Pembina Pancur Batu Perlu dilakukan kegiatan belajar sambil bermain untuk merangsang perkembangan 
kemampuan anak. Keterbatasan ruang bermain dapat disiasati dengan melakukan jenis permainan di dalam ruangan yang tidak membutuhkan tempat yang luas misalnya bermain plastisin untuk merangsang motorik halus anak, senam kesegaran jasmani untuk melatih motorik kasar, bercerita bebas dan bernyanyi untuk merangsang kemampuan bahasa serta kegiatan bermain berkelompok untuk merangsang kemampuan personal sosial.

2. Pendidikan Keperawatan Diharapkan agar dosen dan mahasiswa bekerjasama untuk melakukan kegiatan bermain guna merangsang perkembangan anak di TK Negeri Pembina Pancur Batu Kebupaten Deli Serdang.

3. Penelitian Keperawatan Melakukan penelitian dengan memperbanyak variabel-variabel penelitian. Beberapa faktor yang herediter dan lingkungan mempengaruhi kemampuan perkembangan anak. diserankan untuk melakukan penelitian kualitatif untuk menggali lebiih dalam faktor-faktor yang menyebabkan keterlambatan anak dalam perkembangan motorik halus, motorik kasar, bicara dan bahasa anak.

\section{DAFTAR PUSTAKA}

Almatsier, S. 2009. Prinsip Dasar Ilmu Gizi. Jakarta : Gramedia Pustaka Utama.

Depkes RI. (2012). Keputusan Menteri Kesehatan RI No. 1995/MENKES/SK/XII/2010 tentang Standar Antropometri Penilaian Status Gizi Anak.
Depkes RI, (2009). Pedoman Pelaksanaan Stimulasi, Deteksi dan Intervensi Dini Tumbuh Kembang Anak Ditingkat Pelayanan Kesehatan Dasar. Jakarta

Depkes RI, (2010) Riset Kesehatan Dasar 2010. http://www.riskesdas.litbang,depkes.go.id/download /TabelRiskesdas2010.pdf. Diakses tanggal 13 Desember 2016.

Depkes RI, 2008. Analisis Status Gizi dan Kesehatan Masyarakat. Jakarta

Depkes RI. (2013). Badan Penelitian dan Pengembangan Kesehatan Kementerian Kesehatan. Jakarta: Riskesdas.

Fida, M. (2012). Pengantar Ilmu Kesehatan Anak. Jogjakarta: D. Medika.

Guyton, Arthur C, John E. Hall., 2008. Buku Ajar Fisiologi Kedokteran. Jakarta:EGC

M. Sholeh Kosim, dkk. Buku Ajar Neonatologi. Ikatan Dokter Anak Indonesia, Jakarta. 2012

Madiyantiningtias, E.H., (2015), Hubungan status gizi dengan perkembangan motorik halus pada anak usia 3-5 tahun di Puskesmas Miri-Sragen.

Mumpuni Yekti \& Wulandari Ari., (2010). Cara Jitu Mengatasi Kegemukan. Yogyakarta: Andi.

Nency., (2008). Gizi Anak Balita. Jakarta: Penerbit Universitas Indonesia.

Soetjiningsih, dkk (2013). Tumbuh Kembang Anak. Edisi 2, Jakarta: Buku Kedokteran EGC.

Supariasa, 2001. Penilaian Status Gizi. Jakarta, EGC.

Supariasa, N. DI., Bakri, B., \& Fajar, I., 2002. Penilaian Status Gizi. Jakarta : EGC

Surbaningsih Siti \& Rohmah Fathiyatur (2015). Hubungan Status Gizi dengan Perkembangan Balita Usia 4-5 Tahun di TK ABA Gendingan Yogyakarta. 